\title{
Discussion Leadership in the EFL Classroom
}

\section{Matthew Ryczek \\ Tokyo University of Foreign Studies}

\section{Reference Data:}

Ryczek, M. (2019). Discussion leadership in the EFL classroom. In P. Clements, A. Krause, \& R. Gentry (Eds.), Teacher efficacy, learner agency. Tokyo: JALT. https://doi.org/10.37546/JALTPCP2019-42

In this paper I introduce a teaching approach with the aim to improve English language learners' sense of agency by leading small group discussions. I attempt to demonstrate that by giving students a greater amount of freedom and control over the content of their discussions, their capacity to communicate can improve. This approach was implemented in two 2 nd-year English classes at a public university in Japan during the 2018-2019 academic year. In these classes, students regularly presented news articles related to topics they wanted to discuss and led a group of classmates in a discussion of their topic using their own discussion questions. I address how this learning approach was implemented, including guidance for article selection, presentation, and discussion leadership. I conclude with a discussion of the efficacy of this approach based on feedback from a student survey.

本論では、少人数で構成されたグループディスカッションを進めることによ以学習者の主体性の発達を目的とした指導方 法を紹介する。学生自身が議論の内容,どのように議論を進めるかを自由に決めることによ以、学生のコミュニケーショコ能力 の改善を論証することを試みている。の指導方法は、2018年か52019年に日本の国立大学の2年生を対象とした2 2つの授業 で央践され、これらの授業の中では、各学生が議論したいトピックに関連したニュース記事をグルーブ内で發表し議論をし たい質問項目を選びをての質問をもとにディスカッションを進めた。本論では、学生が適切な記事の選択をするように導くた

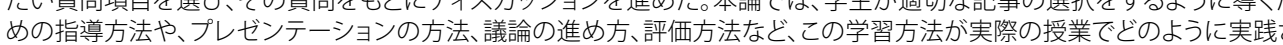
れたか説明する。この方法の効果は授業を受講した学生へのアンケート調查による評価ををとに結論うけけいる。 reating opportunities for greater autonomy and agency over one's learning is one

of the many objectives I have for my students. It is my view that participating in small group discussions can be effective in building students' oral fluency as well as their confidence while communicating in English. Though there are many ways to incorporate discussion into the EFL classroom, it typically consists of an input of background information on the topic of discussion through a reading or task to be completed before class followed by in-class discussions of questions generated by the instructor or curriculum planner.

Although this approach has its benefits, including maximizing student speaking time in English and opportunities for students to express their opinions, it has some drawbacks, especially for more advanced English language learners. In my experience with discussions in class, topics that $\mathrm{I}$ had assumed my students would find interesting, such as the environment, were sometimes received quite negatively by my students and yielded poor quality discussions in class. When I inquired into the reason, my students informed me that they found the topic boring because they had already studied this kind of topic many times in other classes. It is a challenge to select topics of study, which need to be appropriate for all students. Teachers often hesitate to choose controversial topics in their classroom discussions, though they are potentially interesting. This may result in the selection of bland topics that may be boring or uninspiring to students, though appropriate for all learners.

In addition to these difficulties, another drawback of this typical approach to implementing discussion in the language classroom is participation. When students are asked to participate in unstructured discussions in English, certain students will assume leadership positions and dominate the discussion, while others withdraw and communicate less. This unfortunate situation may be inevitable, but if left unchecked it can have a negative impact on less confident students, who may assume a backseat role and further withdraw from communicating in group discussions in the future. These problems, among others, can be resolved by taking a different approach to the English 
discussion with a focus on leadership and greater student control over the content of their discussions. By giving students more autonomy in the classroom, not only their confidence but also their drive to further develop their English knowledge and ability can also improve.

\section{Learner Agency and Autonomy}

Before discussing how it can be promoted, we should begin by defining the term agency, however challenging that may be. According to Giddens (1976, 1984), agency refers to a person's capacity to act or choose a course of action from a range of options. We should think of agency as our ability to take action when provided the opportunity to do so. Agency is the "power to control one's situation, be fully heard, be free from oppression, and have choices" (Oxford, 2003, p. 79). An "agentive" language learner is an active participant in the learning process who can make choices about their behavior and control their actions (Yashima, 2012).

Having agency does not result in uniform behavior, as it is highly dependent on a person's social and cultural background, with its unique communication patterns and strategies. For Ahearn (2001, p. 122), agency is the "socioculturally mediated capacity to act." Second language learners' ability to communicate is mediated by numerous social and cultural factors, or "habitus" according to Bourdieu (1977), and learners demonstrate agency when they overcome these limitations by developing new forms of communication. To have agency requires that the language learner not only be a selfdirected learner but also that they take advantage of learning opportunities in order to collectively make changes, overcome what is given, and generate something new (Engeström, 1987). An agentive learner understands that mastering a second language requires more than understanding its form and structure but also how to "actively engage in constructing the terms and conditions of their own learning" (Lantolf \& Pavlenko, 2001, p. 145).

The ability of the learner to take action requires circumstances that permit that action to occur, and so we need to understand the concept of learner autonomy. Little (1991, p. 4) defined learner autonomy as "a capacity for detachment, critical reflection, decision making, and independent action.” According to Benson (2011), autonomy refers to the ability to take control of one's learning. Though a distinction between learner agency and learner autonomy exists, there is certainly a fair amount of overlap between these two concepts. In fact, the concepts of learner agency and learner autonomy share so much in common that clearly separating the two can be challenging, resulting in the often interchangeable usage of both terms (Toohey, 2007; Toohey \& Norton, 2003).
Despite this challenge, and for the purposes of this paper, autonomy refers to the specific conditions related to the amount of control the learner has over their learning; agency refers to how the learner communicates under those conditions. Autonomy can be given to the learner, through providing opportunities for more student input and control, but agency cannot. Learner agency develops when the student, despite the numerous social and cultural limitations on their ability to communicate in English, takes advantage of the learning opportunities available to them in order to find new methods of communication. By giving students more autonomy, their sense of agency can improve. This paper will outline a learning approach that demonstrates this.

\section{Class Background}

This learning approach was introduced in two required English speaking courses for 2nd-year English majors at a public university in Tokyo, Japan during the 2018-19 academic year. The general learning objective for this course is to improve students' oral fluency and confidence in English. The course is one semester in length, and students in this course are divided into classes of approximately 20 students based on their scores on the TOEIC taken at the beginning of the school year. The English ability of the students ranged from upper intermediate to advanced, including several students with experience studying abroad in English-speaking countries. Students in these courses are typically eager to communicate in English, particularly when in-class communication activities are seen as challenging and worthwhile in their language learning endeavors. Having tried several different approaches to meet the learning needs of these students, I found the approach presented here to be the most effective in motivating the students to challenge themselves to be more autonomous learners with a greater sense of agency over their ability to communicate in English.

\section{Methodology}

Setting for myself the task of creating a course that gives students greater autonomy over their learning, I attempted to design a curriculum that balanced the amount of contro between the teacher and students. Too much instructor control over the course could stifle learner autonomy; too little might result in learner confusion and a fragmented classroom learning environment. I decided to use group discussion as the main approach to practicing English communication but to give students having more control over the specific content being discussed. In designing the course, I wanted to implement some of Dörnyei and Murphy's (2003) principles for promoting learner autonomy in groups of language learners: (a) allow learners choices, (b) give students positions of genuine 
authority, (c) encourage student contributions and peer teaching, (d) encourage project work, and (e) use self-assessment.

The basic structure of the course consisted of weekly article presentations and discussions led by each student. Before class, students were asked to select an appropriate news article based on the theme of that week's class and complete a report for homework. The report consisted of several tasks including a brief summary of the article, the student's reaction to the article, at least two warm-up questions, and two discussion questions about the topic of the article. In class each week, students were divided into random groups of three to four and took turns presenting and discussing their articles. Each student had 15 minutes to present their summary of the article and lead the group in a discussion of their discussion questions. I monitored the students and assisted if necessary, while ensuring that all students had equal amounts of time. Discussion leaders received individual oral peer feedback from their fellow group members after each article presentation and discussion. Written feedback on the quality of their written report, as well as their presentation and discussion, was provided by me to each student every week. Students were also formally assessed three times during the semester on the quality of their presentations and discussion leadership.

\section{Weekly Themes}

In creating a course that gives students a greater amount of autonomy while maintaining whole-class cohesion, I decided to adopt a thematic approach when organizing the content of the course. Each week's lesson focused on a single theme to which students needed to connect their individually chosen articles. The themes I selected for this course consisted of a range of broad contemporary social topics, including culture, education, gender and sexuality, race and ethnicity, and crime and criminal justice. Teacher selection of the weekly themes was important in framing the structure of the course. I selected these specific weekly themes because they are engaging, important, and broad enough that all students are able to select a related article that is of interest to them. Different weekly themes meant that each week's discussions remained fresh and interesting to the students.

Another rationale for adopting this thematic approach was to avoid the course simply becoming a "current events" type of discussion class, with students presenting articles that have no connection to each other. Having a single overarching theme to each lesson helped students to engage in more in-depth and meaningful discussions. And as connections between different topics presented themselves during discussions, students could reevaluate and modify their opinions and thinking. It was my hope that by balancing the teacher's autonomy (theme selection) and student autonomy (article selection) students could engage in more meaningful discussions and create new patterns of communication essential to an agentive learner.

\section{Article Selection}

Even while giving students more control over the content of their discussions, I believe teacher-provided guidance over how that autonomy should be exercised is necessary. I was concerned that by giving the students too much autonomy, the quality of the course could be lowered. In order to maintain class cohesion while giving students the freedom to control the content of their discussions, four guidelines for selecting appropriate articles were provided.

The first guideline for article selection was that the topic of the article must clearly relate to the weekly theme of the class. Because the students would typically have four discussions in each class, all related to a single theme, discussing an unrelated topic could be challenging to the participants as they might not be able to use their ideas from the previous discussions in the unrelated topic's discussion. The next guideline was difficulty. Students were to avoid articles in which the content was overly complicated, as well as articles that were too short in length or too narrow in scope. The third guideline concerned the source of the articles. It was explained to students that an important objective of the course was for them to broaden their understanding of different issues from multiple perspectives, and therefore they should try to seek out a variety of sources for the articles they selected. Finally, students were asked to consider the originality of the articles that they selected. In order to avoid duplicate article presentations in class, students were encouraged to narrow their search parameters to a more specific topic that interested them.

By giving students clear guidance from the beginning of the semester on what constitutes an appropriate article for presentation and discussion, problems encountered later in the semester could be avoided. Though the above guidelines may appear rather restrictive in a paper encouraging learner autonomy, I believe that in order to achieve the goal of creating more agentive learners, it is essential for the teacher to provide a clear framework, within which students can exercise their autonomy as learners. This form of scaffolding should guide and support the students, especially at the beginning of the course, but can be relaxed or removed as students gain more experience and confidence in presenting their articles. 


\section{Discussion Leadership}

Because the aim of this course was to encourage students to be more autonomous learners, rather than only being participants in a discussion, students were asked to lead the discussion of the article they selected each week. It is the discussion leader's responsibility to encourage equal participation from all group members, challenge weakly supported opinions, identify agreements and disagreements, and of course, create a positive communicative atmosphere for the group. However, in addition to practicing these communication skills, one important objective of having a discussion leader is to give students the opportunity to exercise some autonomy over the content of the group's discussion. Giving every student the opportunity to perform the role of discussion leader on a regular basis is essential in maintaining motivation and encouraging them to develop their English communication strategies and techniques as well as foster a sense of agency.

The discussion leader has many responsibilities, including presenting their article's main idea and relevant details, but their primary task is directing the group's discussion of the topic through their own unique discussion questions. Because the discussion leader creates the discussion questions, they have some control over what the group will or will not discuss. This freedom allows for discussions to progress in interesting directions, as what each student finds most interesting about a particular topic is a matter of personal preference. Though multiple students may present articles about the same topic (for example, the issue of banning single-use plastic drinking straws during our environment themed class), these students may ask different questions resulting in very different discussions. One student may choose to focus on the economic impact banning drinking straws may have; another student might choose to discuss how the banning of plastic drinking straws could negatively impact the lives of people with disabilities. Having the opportunity to lead their group's discussion is an opportunity for the student not only to practice oral communication skills, but to experience the autonomy of deciding how to frame their group's discussion of the topic.

\section{Survey Results and Discussion}

In order to gain a better understanding of the efficacy of my approach, a short survey was administered at the end of the semester (see Table 1). Thirty-six responses were received in total from my two classes. All students provided informed consent by answering "yes" to the question I consent that the following information I share in this questionnaire may be used by the instructor for academic purposes. Permission to conduct this research was also given orally by the department head. In survey questions 1 and 2 (not included in
Table 1) the students were asked about their experience with English discussion prior to this class. According to survey results, all 36 of the students had experience participating in English discussions in their classes before taking this course, and 26 students had experienced leading discussions in English. Unfortunately, in what capacity they led the discussions is unclear. What is clear is that these students had experience participating in, as well as in leading, discussions in English prior to taking this class, and therefore might have been be able to evaluate the effectiveness of the approach.

The questionnaire consisted of eight opinion-focused questions about the course. Students were asked to indicate whether they agreed or disagreed with the statement by selecting from five choices: strongly disagree, disagree, neither disagree nor agree, agree, or strongly disagree. Results of Item 1 indicate the students' overall positive impression of using English discussion as a method for improving their English ability. Students also seem to have found leading discussions in class both enjoyable (Item 2) as well as more beneficial to improving their English learning than just being a participant in a discussion (Item 3). Item 4 was an attempt to understand to what degree the students had control over the content of their discussions in other classes. The results indicate that though many students neither agreed nor disagreed with the statement, most students agreed that they did not have much control over the topics discussed in their previous classes.

According to Yashima (2012), agency is most closely associated with motivation, so I wanted to understand what impact this learning approach had on my students' motivation. The results from Item 5 seem to indicate that students found this approach motivating and encouraged them to work hard in class. As Item 6 shows, students felt a personal sense of pride when their discussion was successful, which may be viewed as evidence that they found this learning approach worthwhile. What is more, as Item 7 shows, students appear to have appreciated the challenge of leading a weekly discussion of their own unique topic, and when their discussions were successful they felt a sense of accomplishment. Perhaps being a discussion leader was an opportunity for students to practice methods of communication in English that could allow them to create something "new," as alluded to by Engeström (1987). These survey results illustrate the positive impact this approach had not only on keeping students motivated to learn but also on the individual sense of pride and accomplishment they felt throughout the course.

Although these survey results appear to support the efficacy of this learning approach, the question of whether or not students felt an increased sense of agency over their learning is not as clear. Although measuring learner agency through a student survey may not even be possible, I attempted to see if students took some self-initiative in going beyond the weekly course requirements in Item 8: I attempted to choose more 
Table 1. Student Survey Results $(N=36)$

\begin{tabular}{|c|c|c|c|c|c|}
\hline Questionnaire item & $\begin{array}{l}\text { Strongly } \\
\text { disagree }\end{array}$ & Disagree & $\begin{array}{l}\text { Neither } \\
\text { disagree } \\
\text { nor agree }\end{array}$ & Agree & $\begin{array}{l}\text { Strongly } \\
\text { agree }\end{array}$ \\
\hline $\begin{array}{l}\text { 1. I think having discussions is an } \\
\text { effective method for practicing } \\
\text { English. }\end{array}$ & 0 & $\begin{array}{c}1 \\
(3 \%)\end{array}$ & $\begin{array}{c}2 \\
(6 \%)\end{array}$ & $\begin{array}{c}9 \\
(25 \%)\end{array}$ & $\begin{array}{c}24 \\
(67 \%)\end{array}$ \\
\hline $\begin{array}{l}\text { 2. I think leading a group } \\
\text { discussion in English is more } \\
\text { enjoyable than just participating } \\
\text { in one. }\end{array}$ & 0 & $\begin{array}{c}4 \\
(11 \%)\end{array}$ & $\begin{array}{c}8 \\
(22 \%)\end{array}$ & $\begin{array}{c}12 \\
(33 \%)\end{array}$ & $\begin{array}{c}12 \\
(33 \%)\end{array}$ \\
\hline $\begin{array}{l}\text { 3. I think leading a group } \\
\text { discussion in English is more } \\
\text { beneficial to my English learning } \\
\text { than just participating in one. }\end{array}$ & 0 & $\begin{array}{c}5 \\
(14 \%)\end{array}$ & $\begin{array}{c}2 \\
(6 \%)\end{array}$ & $\begin{array}{c}12 \\
(33 \%)\end{array}$ & $\begin{array}{c}17 \\
(47 \%)\end{array}$ \\
\hline $\begin{array}{l}\text { 4. In my experience with } \\
\text { English discussion, the topic of } \\
\text { the discussion and discussion } \\
\text { questions were typically decided } \\
\text { for me. }\end{array}$ & $\begin{array}{c}1 \\
(3 \%)\end{array}$ & $\begin{array}{c}3 \\
(8 \%)\end{array}$ & $\begin{array}{c}13 \\
(36 \%)\end{array}$ & $\begin{array}{c}16 \\
(44 \%)\end{array}$ & $\begin{array}{c}3 \\
(8 \%)\end{array}$ \\
\hline $\begin{array}{l}\text { 5. I think having control over } \\
\text { the topic of discussion and } \\
\text { discussion questions motivated } \\
\text { me to work harder in this class. }\end{array}$ & 0 & $\begin{array}{c}1 \\
(3 \%)\end{array}$ & $\begin{array}{c}5 \\
(14 \%)\end{array}$ & $\begin{array}{c}18 \\
(50 \%)\end{array}$ & $\begin{array}{c}12 \\
(33 \%)\end{array}$ \\
\hline $\begin{array}{l}\text { 6. I felt proud when my } \\
\text { discussion went well. }\end{array}$ & 0 & $\begin{array}{c}1 \\
(3 \%)\end{array}$ & $\begin{array}{c}2 \\
(6 \%)\end{array}$ & $\begin{array}{c}12 \\
(33 \%)\end{array}$ & $\begin{array}{c}21 \\
(58 \%)\end{array}$ \\
\hline $\begin{array}{l}\text { 7. If/when my discussion } \\
\text { went well, I felt like I had } \\
\text { accomplished something } \\
\text { challenging. }\end{array}$ & 0 & $\begin{array}{c}4 \\
(11 \%)\end{array}$ & $\begin{array}{c}3 \\
(8 \%)\end{array}$ & $\begin{array}{c}12 \\
(33 \%)\end{array}$ & $\begin{array}{c}17 \\
(47 \%)\end{array}$ \\
\hline $\begin{array}{l}\text { 8. I attempted to choose more } \\
\text { challenging articles to present } \\
\text { and discuss each week, rather }\end{array}$ & $\begin{array}{c}2 \\
(6 \%)\end{array}$ & $\begin{array}{c}6 \\
(17 \%)\end{array}$ & $\begin{array}{c}11 \\
(31 \%)\end{array}$ & $\begin{array}{c}9 \\
(25 \%)\end{array}$ & $\begin{array}{c}8 \\
(22 \%)\end{array}$ \\
\hline
\end{tabular}

challenging articles to present and discuss each week, rather than "easy" ones. It was hoped that by giving students more autonomy over the content of their discussions, though some students would inevitably take advantage of this and turn in the minimal amount of work required, some students would find this autonomy liberating and would do more than the stated class requirements. Any indication that students were making this kind of effort, and going above and beyond what is required, could be evidence of learner agency. According to the survey results, $31 \%$ of respondents neither agreed nor disagreed with this statement; $47 \%$ agreed or strongly agreed. This seems to indicate that many students challenged themselves each week by going beyond the minimum requirements of the course. Although this may not be clear evidence that this approach resulted in an increase in learner agency, the results of this survey indicate some positive effects this teaching approach can have on learners' motivation and capacity to take action over their learning when provided the opportunity to do so.

\section{Conclusion}

The survey results indicate that giving students the opportunity not only to select the topics of their discussions but also act as discussion leaders may increase learner agency. Students responded that they were motivated by leading discussions and challenged themselves to have interesting and engaging discussions with their classmates, which may indicate their feeling some sense of agency over their learning. Despite the challenges of measuring agency via a student survey, because students may not be able to accurately evaluate their own sense of such a complex concept as agency, giving language learners more opportunities for autonomy in the classroom can yield positive outcomes, particularly an increase in motivation and pride in the quality of their discussions. The findings and reflections presented in this paper may be valuable to language teachers who are interested in finding new ways to challenge their students to be more autonomous learners, especially for teachers of advanced English classes who may be unsatisfied with their current approach to implementing discussion in their classrooms. Due to the small sample size and the short length of time this approach was implemented, application of the findings presented here is limited. Further research on the efficacy of this approach could benefit from the addition of open-ended survey questions, which could help in gaining a deeper understanding of the students' impressions of their sense of agency. Despite the limitations of this research, it is hoped that this paper can serve as a reference for teachers in search of a method for encouraging more student autonomy in their classrooms.

than "easy" ones. 


\section{Bio Data}

Matthew Ryczek is a visiting lecturer in the Center for Global Language and Society in Higher Education at Tokyo University of Foreign Studies. His interests include learner autonomy, learner agency, and content and language integrated learning (CLIL). matthewlryczek@gmail.com

\section{References}

Ahearn, L. M. (2001). Language and agency. Annual Review of Anthropology, 30(1), 109-137. https://doi.org/10.1146/annurev.anthro.30.1.109

Benson, P. (2011). Teaching and researching autonomy (2nd ed.). London, England: Pearson.

Bourdieu, P. (1977). Outline of a theory of practice (R. Nice, Trans.). Cambridge, England: Cambridge University Press.

Dörnyei, Z., \& Murphy T. (2003). Group dynamics in the language classroom. Cambridge, England: Cambridge University Press.

Engeström, Y. (1987). Learning by expanding: An activity theoretical approach to developmental research. Helsinki, Finland: Orienta-Konsultit.

Giddens, A. (1976). New rules of sociological method: A positive critique of interpretative sociologies. London: Hutchinson.

Giddens, A. (1984). The constitution of society: Outline of the theory of structuration. Berkeley: University of California Press.

Lantolf, J. P., \& Pavlenko, A. (2001). (S)econd (L)anguage (A)ctivity theory: Understanding second language learners as people. In M. P. Breen (Ed.), Learner contributions to language learning: New directions in research (pp. 141-58). Harlow: Longman.

Little, D. (1991) Learner autonomy 1: Definitions, issues and problems. Dublin: Authentik.

Oxford, R. L. (2003). Toward a more systematic model of L2 learner autonomy. In D. Palfreyman \&

R. C. Smith (Eds.), Learner autonomy across cultures: Language education perspectives (pp. 75-91). New York: Palgrave Macmillan.

Toohey, K. (2007). Conclusion: Autonomy/agency through socio-cultural lenses. In A. Barfield \& S. H. Brown (Eds.), Reconstructing autonomy in language education: Inquiry and innovation (pp. 231242). Basingstoke: Palgrave Macmillan.

Toohey, K., \& Norton, B. (2003). Learner autonomy as agency in sociocultural settings. In D. Palfreyman \& R. C. Smith (Eds.), Learner autonomy across cultures: Language education perspectives (pp. 58-72). New York: Palgrave Macmillan.

Yashima, T. (2012). Agency in second language acquisition. The encyclopedia of applied linguistics. Hoboken: Wiley-Blackwell. https://doi.org/10.1002/9781405198431.wbeal0016 